\title{
Draft genomes of "Pectobacterium peruviense" strains isolated from fresh water in France
}

\author{
Pierre Faye, Claire Bertrand, Jacques Pédron and Marie-Anne Barny ${ }^{*}$ (]
}

\begin{abstract}
Bacteria belonging to the genus Pectobacterium are responsible for soft rot disease on a wide range of cultivated crops. The "Pectobacterium peruviense" specie, recently proposed inside the Pectobacterium genus, gathers strains isolated from potato tubers cultivated in Peru at high altitude. Here we report the draft genome sequence of two strains belonging to "P. peruviense" isolated from river water in France indicating that the geographic distribution of this specie is likely to be larger than previously anticipated. We compared these genomes with the one published from the "P. peruviense" specie type strain isolated in Peru.
\end{abstract}

Keywords: Pectobacterium peruviense, Soft rot, Plant pathogen, Water, France

\section{Introduction}

The Pectobacterium genus [1] gathers important plant pathogens that cause soft rot disease on a large variety of plant species [2]. Given their ability to cause disease on major crops, such as potato, Pectobacterium sp. have mainly been isolated from diseased plant during initial outbreak or sustained epidemic and their descriptions outside of agricultural context is scarce [3].

The classification of the Pectobacterium genus has been subject to extensive revision over the last decade. It is currently subdivided in 7 species; $P$. carotovorum [1], P. atrosepticum [4], P. betavasculorum [4], P. wasabiae [4], P. aroidearum [5] P. polaris [6], P. parmentieri [7] and the recently proposed " $P$. peruviense" [8]. The $P$. carotovorum specie is heterogeneous and is currently subdivided several recognized subspecies, $P$. carotovorum subsp. carotovorum $[9,10], P$. carotovorum subsp. odoriferum $[9,10]$ and proposed subspecies " $P$. carotovorum subsp. actinidiae" [11] and "P. carotovorum subsp. brasiliense" [12]. This heterogeneity led to assignation of many Pectobacterium isolates to P. carotovorum. One example is the strain UG32 (also named IFB5232, SCRI179, LMG30269 and PCM2893) that was initially described as P. carotovorum subsp. carotovorum

\footnotetext{
* Correspondence: marie-anne.barny@sorbonne-universite.fr Institute of Ecology and Environmental sciences-Paris, Sorbonne Université, INRA, 4 place Jussieu, F-75 252 Paris, France
}

and is now the proposed type strain of the " $P$. peruviense" specie $[8,13]$. All the strains described so far in the "P. peruviense" specie have been isolated in Peru in the seventies during the twentieth century from potato plants cultivated at high altitude $(2400-3800 \mathrm{~m})$. Here we described the draft genome sequence of two strains A97-S13-F16 and A350-S18-N16 isolated in February and November 2016 at different altitudes in the Durance river stream in France.

\section{Organism information Classification and features}

Strain A97-S13-F16 was isolated in february 2016 from fresh water sampled in the river Durance while strain A350-S18-N16 was isolated in november 2016 from fresh water sampled in river Bléone, close to the confluent with river Durance. The fresh water parameters measured at the sampling times respectively were the following respectively for A97-S13-F16 and A350-S18N16 sampled water: temperature $6.4{ }^{\circ} \mathrm{C}$ and $10.4{ }^{\circ} \mathrm{C}$; turbidity $2.69 \mathrm{NTU}$ and $145 \mathrm{NTU}$, conductivity $629 \mu \mathrm{S}$ and $629 \mu \mathrm{S}$. Following sampling, $500 \mathrm{ml}$ of fresh water was filtered through $0.2 \mu \mathrm{m}$ pore filters (Sartorius cellulose acetate filters), the bacteria present on the filters were suspended in $1 \mathrm{ml}$ sterile distilled water and $100 \mu \mathrm{l}$ of the suspension were poured onto semi selective modified single-layers $\mathrm{CVP}_{\mathrm{AG} 366}$ plates (same medium as

(C) The Author(s). 2018 Open Access This article is distributed under the terms of the Creative Commons Attribution 4.0 International License (http://creativecommons.org/licenses/by/4.0/), which permits unrestricted use, distribution, and reproduction in any medium, provided you give appropriate credit to the original author(s) and the source, provide a link to the Creative Commons license, and indicate if changes were made. The Creative Commons Public Domain Dedication waiver (http://creativecommons.org/publicdomain/zero/1.0/) applies to the data made available in this article, unless otherwise stated. 
described in [14] except that tryptone was not added to the medium, hereafter described as CVP). After 2 days of growth at $28{ }^{\circ} \mathrm{C}$, two strains forming pits on CVP medium were further isolated, named A97-S13-F16 and A350-S18-N16 and stored in 40\%/60\% glycerol/ LB liquid medium (10 g tryptone, $5 \mathrm{~g}$ yeast extract, $10 \mathrm{~g} \mathrm{NaCl}$ per one liter of medium) at $-80^{\circ} \mathrm{C}$.

Cells of both strains are rod shaped with length of approximately $2 \mu \mathrm{m}$ in the exponential growth phase on LB medium (Fig. 1) and both strains are macerating potato tubers (Additional file 1: Figure S1). They are forming isolated colonies after $24 \mathrm{~h}$ at $28{ }^{\circ} \mathrm{C}$ on LB-15 g agar medium and after $48 \mathrm{~h}$ at $28{ }^{\circ} \mathrm{C}$ on TSA $10 \%$ medium (1,5 g tryptone, $0,5 \mathrm{~g}$ soy peptone, $0,5 \mathrm{~g} \mathrm{NaCl}, 15 \mathrm{~g}$ agar per one liter of medium) and are inducing pits in CVP medium after $48 \mathrm{~h}$ at $28{ }^{\circ} \mathrm{C}$.

Amplification and sequencing of the gapA house keeping gene was recently described to rapidly characterize the different Pectobacterium species [15]. The gapA sequences of strains A97-S13-F16 and A350-S18-N16 clustered with the one of proposed "P. peruviense" type strain (Fig. 2A) and the clusterization of both strains with "P. peruviense" was confirmed through MLSA analysis of full genomes (Fig. 2B).

General feature of A97-S13-F16 and A350-S18-N16 are indicated in Table 1.

\section{Genome sequencing information Genome project history}

The aim of the project was to described Pectobacterium sp. isolated from environmental samples outside agricultural context. Fresh water sampling was performed in the river Durance and its tributaries in 2016. Amongst the isolated strains, the two strains A97-S13-F16 and
A350-S18-N16, isolated in different locations and at different months in the river stream, were selected for sequencing following amplification and sequencing of their gapA house keeping gene because phylogenetic analysis of their gapA sequences positioned both gapA sequences close to the gapA sequence of the recently proposed " $P$. peruviense" type strain UGC32 $[8,13,15]$.

\section{Growth conditions and DNA isolation}

After isolation from fresh water in 2016, strains A97-S13-F16 and A350-S18-N16 have been stored in $40 \% / 60 \%$ glycerol /LB medium at $-80{ }^{\circ} \mathrm{C}$. For preparation of genomic DNA, the strains were first grown overnight at $28{ }^{\circ} \mathrm{C}$ on solid LB medium. A single colony was then pick up and grown overnight in $2 \mathrm{ml}$ of liquid LB medium at $28{ }^{\circ} \mathrm{C}$ with $120 \mathrm{rpm}$ shaking. Bacterial cells were harvested by centrifugation $(5 \mathrm{~min}$ at $12,000 \mathrm{rpm}$ ) and DNA was extracted with the wizard ${ }^{\circ}$ genomic DNA extraction kit (Promega) following the supplier specification. DNA was suspended in $100 \mu \mathrm{l}$ of sterile distilled water and the quantity and quality of DNA was assessed by nano-drop measurement, spectrophotometry analysis and gel analysis.

\section{Genome sequencing and assembly}

Genome sequencing was performed at the next generation sequencing core facilities of the Institute for Integrative Biology of the Cell, Bât. 21, Avenue de la Terrasse 91,190 Gif-sur-Yvette Cedex France. Nextera DNA libraries were prepared from $50 \mathrm{ng}$ of high quality genomic DNA. Paired end $2 \times 75$ bp sequencing was performed on an Illumina NextSeq500 instrument, with a High Output 150 cycle kit.

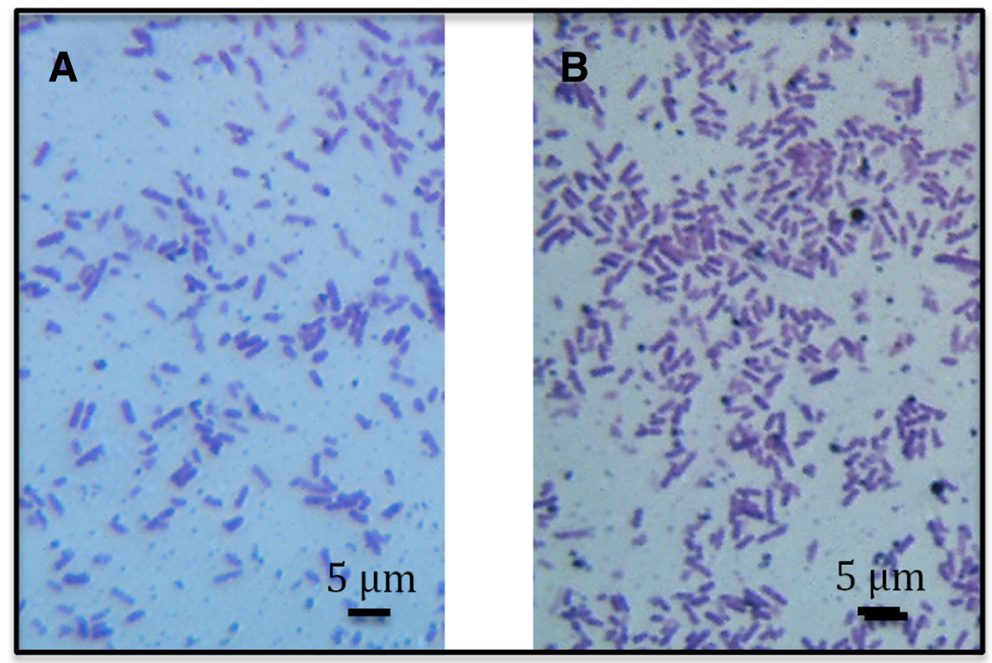

Fig. 1 Photomicrographs of Gram stained exponentially growing "P. peruviense" cells. (a) strain A97-S13-F16, (b) A350-S18-N16. A light microscope with 100X magnification was used. These photomicrographs show the rod shaped forms of both strains. The bar scale represent $5 \mu \mathrm{m}$ 

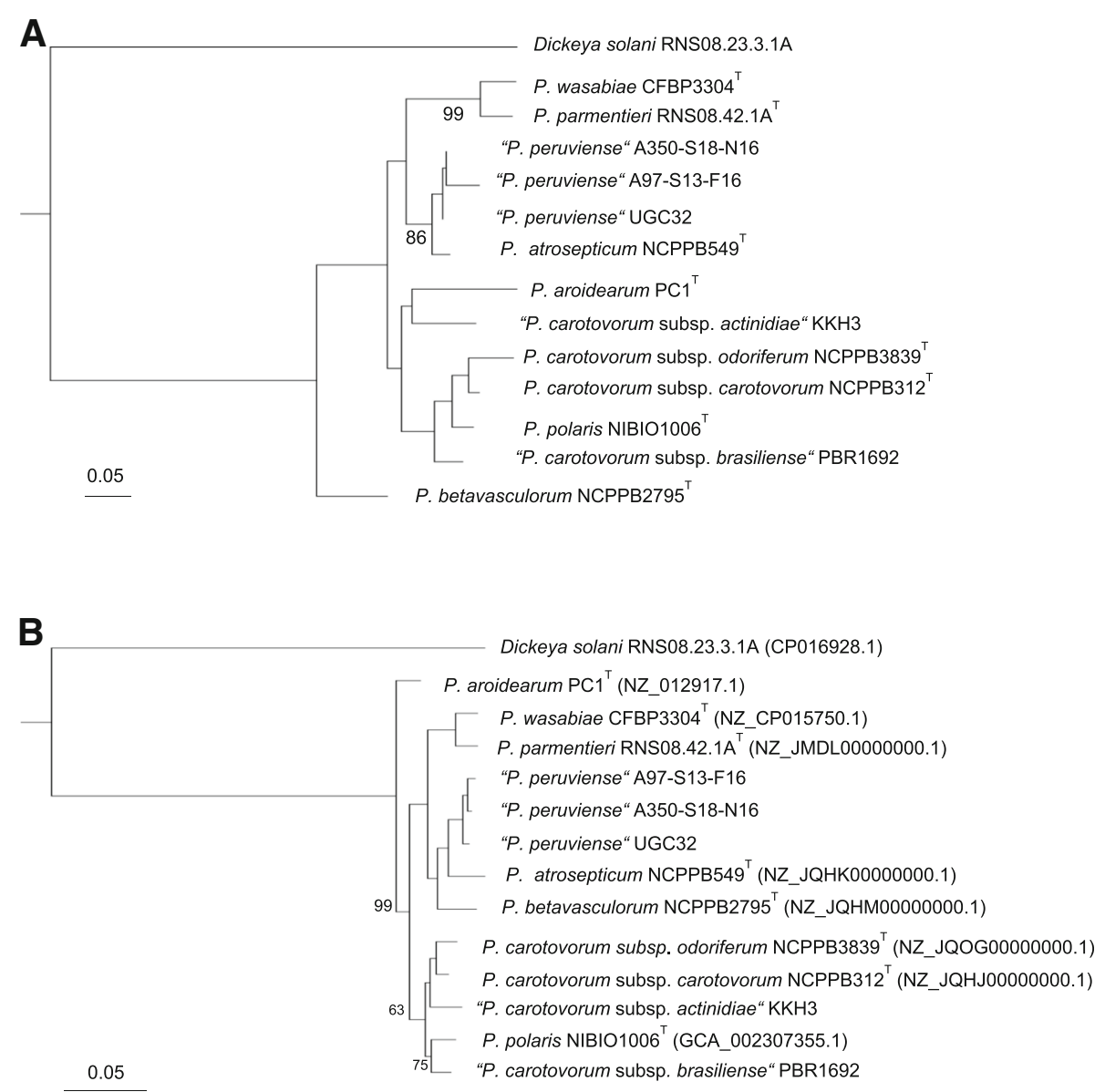

Fig. 2 Phylogenetic trees of "P. peruviense" strains and strains of other Pectobacterium species and subspecies. a Phylogenetic tree constructed from the gapA nucleotide sequences. Sequences were aligned using the MUSCLE software [24] and the alignments were filtered by using the program GBLOCKS [25].Tree was computed using PHYML [26]. One hundred bootstrap replicates were performed to assess the statistical support of each node. Bootstrap support values (percentages) are indicated if superior to 95\%. gapA sequences were retrieved from full genome of type strains (accession numbers are indicated in Fig. 1b) or obtained from the sequenced gapA amplicon for strains A97-S13-F16 and A350-S18-N16. b Phylogenetic tree constructed from concatenated sequences of 1266 homologous amino acid sequences. Before concatenation, the homologous sequences of each gene were aligned using the MUSCLE software [24] and the alignments were filtered by using the program GBLOCKS [25]. Tree was computed using PHYML [26]. One hundred bootstrap replicates were performed to assess the statistical support of each node. Bootstrap support values (percentages) are shown if less than 100\%. The accession number for each genome is indicated inside brackets after the strain name. Dickeya solani RNS08.23.3.1.A was used as outgroup. Type strains are marked with T after the strain name

CLC Genomics Workbench (Version 9.5.2, Qiagen Bioinformatics) was used to assemble 30,066,500 (mean length $53 \mathrm{bp}$ ) and 8,174,334 reads (mean length $52 \mathrm{bp}$ ) for strains A97-S13-F16 and A350-S18-N16 respectively. Final sequencing coverages were $331 \times$ and $86 \times$ with 61 and 73 scaffolds for strains A97-S13-F16 and A350-S18N16 respectively (Table 2).

\section{Genome annotation}

Coding sequences were predicted using the RAST server [16] with the Glimmer 3 prediction tool [17]. COG assignments and Pfam domain predictions were done using the Web CD-Search Tool [18]. CRISPRFinder [19] was used to detect CRISPRs. Signal peptide and transmembrane domain were detected with the SignalP 4.1
Server [20] and transmembrane helices were predicted with TMHMM [21].

\section{Genomes properties}

The "P. peruviense" A97-S13-F16 draft genome contains $4,775,191$ bp with a GC content of $51 \%$. Total predicted genes are 4503 while predicted protein coding genes are 4459 and RNA genes 44. The final assembly comprised 61 scaffolds. Among the predicted genes, $72.21 \%$ have a predicted function, $79.91 \%$ were assigned to COG and $85.40 \%$ have a predicted Pfam domain. Among the predicted proteins, 392 have a predicted signal peptide while 1090 contain a predicted transmembrane helix. Three CRIPS repeats array were detected in this genome. 
Table 1 Classification and general features of strains A97-S13-F16 and A350-S18-N16

\begin{tabular}{|c|c|c|c|}
\hline MIGS ID & Property & Term & Evidence code $^{a}$ \\
\hline & \multirow[t]{8}{*}{ Classification } & Domain Bacteria & TAS [14] \\
\hline & & Phylum Proteobacteria & TAS [15] \\
\hline & & Class Gammaproteobacteria & TAS [16] \\
\hline & & Order Enterobacterale & TAS [17] \\
\hline & & Family Pectobacteriaceae & TAS [17] \\
\hline & & Genus Pectobacterium & TAS [18] \\
\hline & & Species Pectobacterium peruviense & \multirow[t]{2}{*}{ NAS } \\
\hline & & strains: A97-S13-F16 and A350-S18-N16 & \\
\hline & Gram stain & Negative & NAS \\
\hline & Cell shape & Rod & IDA \\
\hline & Motility & Motile & IDA \\
\hline & Sporulation & Non sporulating & NAS \\
\hline & Temperature range & Able to grow at $25^{\circ} \mathrm{C}-28{ }^{\circ} \mathrm{C}$ & IDA \\
\hline & Optimum temperature & Able to grow at $20^{\circ} \mathrm{C}-30^{\circ} \mathrm{C}$ & NAS \\
\hline & $\mathrm{pH}$ range; Optimum & Unknown & NAS \\
\hline & Carbon source & Ability to degrade polypectate & IDA \\
\hline MIGS-6 & Habitat & Isolated from water, & IDA \\
\hline MIGS-6.3 & Salinity & Able to grow in $1 \% \mathrm{NaCL}$ & IDA \\
\hline MIGS-22 & Oxygen requirement & Facultative anaerobic & NAS [17] \\
\hline MIGS-15 & Biotic relationship & Free-living & IDA \\
\hline MIGS-14 & Pathogenicity & Ability to rot potato tubers & IDA \\
\hline \multirow[t]{2}{*}{ MIGS-4 } & \multirow[t]{2}{*}{ Geographic location } & A97-S13-F16, river Durance France & \multirow[t]{2}{*}{ IDA } \\
\hline & & A359-S18-N18, river Bléone France & \\
\hline \multirow[t]{2}{*}{ MIGS-5 } & \multirow[t]{2}{*}{ Sample collection } & A97-S13-F16, 1st February 2016 & \multirow[t]{2}{*}{ IDA } \\
\hline & & A359-S18-N18, 19th November 2016 & \\
\hline \multirow[t]{2}{*}{ MIGS-4.1 } & \multirow[t]{2}{*}{ Latitude } & A97-S13-F16, 44.701667 & \multirow[t]{2}{*}{ IDA } \\
\hline & & A359-S18-N18, 44.038631 & \\
\hline \multirow[t]{2}{*}{ MIGS-4.2 } & \multirow[t]{2}{*}{ Longitude } & A97-S13-F16, 6.599693 & \multirow[t]{2}{*}{ IDA } \\
\hline & & A359-S18-N18, 5.967728 & \\
\hline \multirow[t]{2}{*}{ MIGS-4.4 } & \multirow[t]{2}{*}{ Altitude } & A97-S13-F16, $907 \mathrm{~m}$ & \multirow[t]{2}{*}{ IDA } \\
\hline & & A359-S18-N18, $438 \mathrm{~m}$ & \\
\hline
\end{tabular}

${ }^{a}$ Evidence codes - IDA Inferred from Direct Assay, TAS Traceable Author Statement (i.e., a direct report exists in the literature), NAS Non-traceable Author Statement (i.e., not directly observed for the living, isolated sample, but based on a generally accepted property for the species, or anecdotal evidence). These evidence codes are from the Gene Ontology project [20]

The "P. peruviense" A350-S18-N16 draft genome contains $4,871,019$ bp with a GC content of $51,1 \%$. Total predicted genes are 4635 while predicted protein coding genes are 4487 and RNA genes 48 . The final assembly comprised 73 scaffolds. Among the predicted genes, $72.01 \%$ have a predicted function, $78.77 \%$ were assigned to GOG and $85.09 \%$ have a predicted Pfam domain. Among the predicted proteins, 395 have a predicted signal peptide while 1095 contain a predicted transmembrane helix. Two CRIPS repeats array were detected in this genome.
The properties and the statistics of the two draft genomes are summarized in Tables 3 and 4 .

\section{Insight from genome sequences}

Genome comparison between A97-S13-F16 and A350-

S18-N16 and the genome of representative species of the Pectobacterium genus

A phylogenetic tree, constructed from concatenated sequences of 1266 homologs proteins, clustered the A97-S13-F16 and A350-S18-N16 strains together, close to UGC32 the proposed "P. peruviense" type strain 
Table 2 Genome sequencing project information

\begin{tabular}{|c|c|c|c|}
\hline \multirow[t]{2}{*}{ MIGS ID } & \multirow[t]{2}{*}{ Property } & P. Peruviense & \multirow{2}{*}{$\begin{array}{l}\text { P. Peruviense } \\
\text { A350-S18-N16 }\end{array}$} \\
\hline & & A97-S13-F16 & \\
\hline & Finishing quality & 61 scaffolds & 73 scaffolds \\
\hline MIGS-28 & Libraries used & Nextera DNA Library & Nextera DNA Library \\
\hline MIGS 29 & Sequencing platforms & Illumina NS500 & Illumina NS500 \\
\hline MIGS 31.2 & Fold coverage & $331 x$ & $86 \mathrm{X}$ \\
\hline \multirow[t]{2}{*}{ MIGS 30} & Assemblers & CLC Genomics & CLC Genomics \\
\hline & & Workbench V 9.5.2 & Workbench V 9.5.2 \\
\hline \multirow[t]{6}{*}{ MIGS 32} & Gene calling method & Glimmer 3 & Glimmer 3 \\
\hline & Locus Tag & A97-S13-F16 & A350-S18-N16 \\
\hline & Genbank ID & PYUO01000000 & PYU00100000 \\
\hline & GenBank Date of Release & 10th july 2018 & 10th july 2018 \\
\hline & GOLD ID & & \\
\hline & BIOPROJECT & PRJNA445781 & PRJNA445781 \\
\hline \multirow[t]{2}{*}{ MIGS 13} & Source Material Identifier & CFBP8625 ${ }^{a}$ & CFBP8626 ${ }^{\mathrm{a}}$ \\
\hline & Project relevance & Environment & Environment \\
\hline
\end{tabular}

${ }^{a}$ Strains A97-S13-F16 and A350-S18-N16 are available at the CIRM-CFBP Collection under the indicated numbers

(Fig. 1B). ANIb were further calculated between genomes of strains A97-S13-F16 and A350-S18-N16 and the genomes of described Pectobacterium species and subspecies (Additional file 2: Table S1). Pairwise ANIb values between the three "P. peruviense" genomes, A97-S13-F16 and A350-S18N16 and UGC32, were above 97,5\%. Pairewise ANIb values of these three "P. peruviense" genomes with genomes of other Pectobacterium species and subspecies were below $94 \%$. dDDH is an in silico method to approach the wet-lab $\mathrm{DDH}$ method as closely as possible [22]. $\mathrm{dDDH}$ were calculated between the genomes of A97-S13-F16 and A350-S18-N16 and Pectobacterium genomes representative of known species and subspecies (Additional file 2: Table S1). dDDH values between A350-S18-N16, A97-S13-F16 genomes and the proposed "P. peruviense" UGC32 genomes were above $79 \%$, well above the $70 \%$ species boundary. When pairwise calculations were performed between these three genomes with those of known Pectobacterium species and subspecies the estimated $\mathrm{dDDH}$ values dropped below $54 \%$, well below the species boundary. This confirmed that

Table 3 Genome statistics

\begin{tabular}{|c|c|c|c|c|}
\hline \multirow[t]{2}{*}{ Attribute } & \multicolumn{2}{|c|}{ P. peruviense A97-S13-F16 } & \multicolumn{2}{|c|}{ P. peruviense A350-S18-N16 } \\
\hline & Value & $\%$ of Total & Value & $\%$ of Total \\
\hline Genome size (pb) & $4,755,191$ & 100.00 & $4,871,019$ & 100.00 \\
\hline DNA coding (bp) & $4,108,775$ & 86.41 & $4,211,847$ & 86.47 \\
\hline DNA G + C (pb) & $2,425,147$ & 51.00 & $2,489,091$ & 51.10 \\
\hline DNA scaffolds & 61 & & 73 & \\
\hline Total genes & 4503 & 100.00 & 4635 & 100.00 \\
\hline Protein coding genes & 4459 & 99.02 & 4587 & 98.96 \\
\hline RNA genes & 44 & 0.97 & 48 & 1.03 \\
\hline Pseudo genes & NA & & NA & \\
\hline Genes in internal clusters & NA & & NA & \\
\hline Genes with function prediction & 3252 & 72.21 & 3338 & 72.01 \\
\hline Genes assigned to COGs & 3563 & 79.91 & 3613 & 78.77 \\
\hline Genes with Pfam domains & 3808 & 85.40 & 3903 & 85.09 \\
\hline Genes with signal peptides & 392 & 8.79 & 395 & 8.52 \\
\hline Genes with transmembrane helices & 1090 & 24.44 & 1095 & 23.62 \\
\hline CRISPR repeats & 3 & & 2 & \\
\hline
\end{tabular}


Table 4 Number of genes associated with the 25 COG functional categories

\begin{tabular}{|c|c|c|c|c|c|}
\hline \multirow[t]{3}{*}{ Code } & \multirow{2}{*}{\multicolumn{2}{|c|}{$\frac{\text { P. peruviense }}{\text { A97-S13-F16 }}$}} & \multirow{2}{*}{\multicolumn{2}{|c|}{$\frac{\text { P. peruviense }}{\text { A350-S18-N16 }}$}} & \multirow[t]{3}{*}{ Description } \\
\hline & & & & & \\
\hline & Value & \%age & Value & \%age & \\
\hline$E$ & 366 & 8.21 & 367 & 8.00 & Amino acid transport and metabolism \\
\hline G & 362 & 8.12 & 356 & 7.76 & Carbohydrate transport and metabolism \\
\hline D & 41 & 0.92 & 43 & 0.94 & $\begin{array}{l}\text { Cell cycle control, cell division, chromosome } \\
\text { partitioning }\end{array}$ \\
\hline N & 110 & 2.47 & 107 & 2.33 & Cell motility \\
\hline M & 239 & 5.36 & 244 & 5.32 & Cell wall/membrane/envelope biogenesis \\
\hline H & 167 & 3.75 & 167 & 3.64 & Coenzyme transport and metabolism \\
\hline Z & 1 & 0.02 & 1 & 0.02 & Cytoskeleton \\
\hline V & 85 & 1.91 & 90 & 1.96 & Defense mechanisms \\
\hline C & 226 & 5.07 & 225 & 4.91 & Energy production and conversion \\
\hline W & 4 & 0.09 & 4 & 0.09 & Extracellular structures \\
\hline S & 202 & 4.53 & 209 & 4.56 & Function unknown \\
\hline G & 204 & 4.58 & 206 & 4.49 & General function prediction only \\
\hline P & 242 & 5.43 & 240 & 5.23 & Inorganic ion transport and metabolism \\
\hline U & 82 & 1.84 & 91 & 1.98 & $\begin{array}{l}\text { Intracellular trafficking, secretion, and vesicular } \\
\text { transport }\end{array}$ \\
\hline । & 103 & 2.31 & 102 & 2.20 & Lipid transport and metabolism \\
\hline$x$ & 23 & 0.52 & 57 & 1.24 & Mobilome: prophages, transposons \\
\hline $\mathrm{F}$ & 90 & 2.02 & 91 & 1.98 & Nucleotide transport and metabolism \\
\hline O & 152 & 3.41 & 152 & 3.31 & $\begin{array}{l}\text { Posttranslational modification, protein turnover, } \\
\text { chaperones }\end{array}$ \\
\hline L & 127 & 2.85 & 127 & 2.77 & Replication, recombination and repair \\
\hline A & 1 & 0.02 & 1 & 0.02 & RNA processing and modification \\
\hline Q & 59 & 1.32 & 59 & 1.29 & $\begin{array}{l}\text { Secondary metabolites biosynthesis, transport and } \\
\text { catabolism }\end{array}$ \\
\hline $\mathrm{T}$ & 146 & 3.27 & 148 & 3.23 & Signal transduction mechanisms \\
\hline K & 291 & 6.53 & 287 & 6.26 & Transcription \\
\hline J & 238 & 5.34 & 239 & 5.21 & Translation, ribosomal structure and biogenesis \\
\hline- & 898 & 20.14 & 974 & 21.23 & Not in COGs \\
\hline
\end{tabular}

The total \%age is based on the total number of protein coding genes in the genome

A97-S13-F16 and A350-S18-N16 belong to the " $P$. peruviense" specie.

\section{Genomes comparison between the " $P$. peruviense" strains}

The phylogenetic trees (Fig. 2) indicate that strains A97-S13-F16 and A350-S18-N16 are more closely related to each other than they are from the " $P$. peruviense" type strain UGC32. To further gain insight into the distance between the three " $P$. peruviense" strains, we looked for shared and unique genes between genomes of strains A97-S13-F16, A350-S18-N16 and UGC32 type strain (Fig. 3). A97-S13-F16, A350-S18-N16 and UGC32 strains contain respectively a pool of specific genes of 292, 414 and 346 . The slightly higher pool of specific genes observed in strain A350-S18-N16 could be partly related to its higher content of mobile genetic elements inserted in its genome as described in Table 4. Indeed, we observed 3 clusters of phage-related genes in strain A350-S18-N16, only one being also detected in strain A97-S13-F16. The Venn diagram indicated that 4129 genes are shared between strains A97-S13-F16 and A350-S18-N16 while only 3757 and 3765 genes are respectively shared between the type strain UGC32 and A97-S13-F16 / A350-S18-N16. This confirmed that A97S13-F16 and A350-S18-N16 genomes are more closely related to each other than they are with the genome of the proposed type strain UGC32. 


\section{A350-S18-N16 A97-S13-F16}

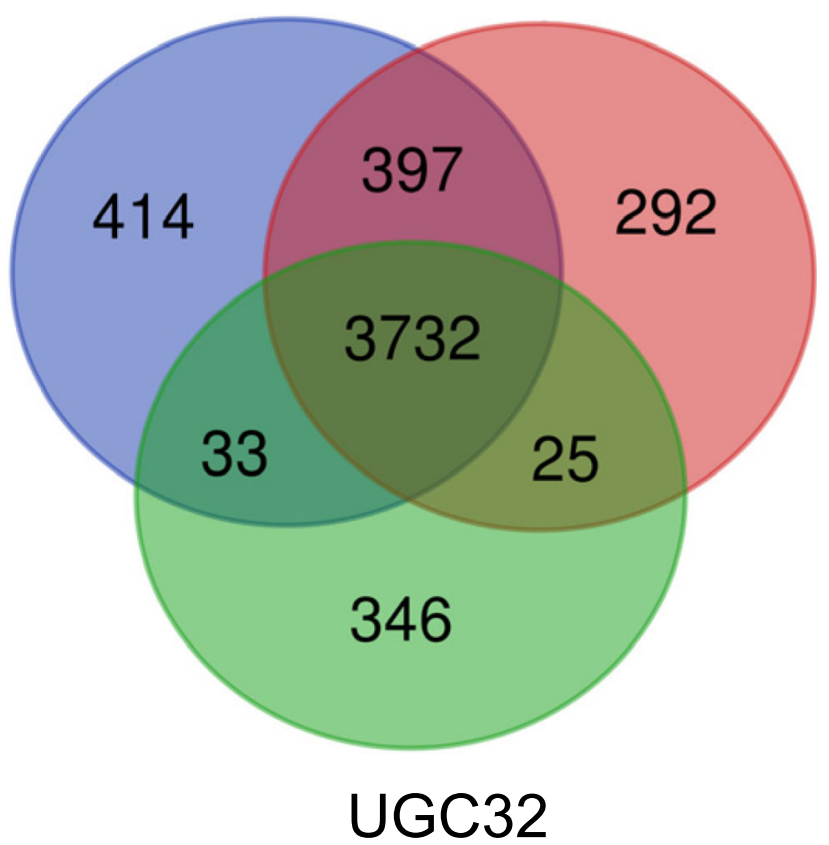

Fig. 3 Venn diagram. Shared and unique genes between the genomes of "P. peruviense" A97-S13-F16 and A350-S18-N16 and the proposed "P. peruviense" type strain UGC32. Orthology was assumed using a threshold of $80 \%$ identity on at least $80 \%$ of the protein length

\section{Conclusions}

In this study we presented the draft genome sequences of two strains of "P. peruviense" isolated from fresh water in river stream in France. The "P. peruviense" specie has recently been proposed and, until our study, the described strains belonging to the " $P$. peruviense" specie have all been isolated on potato tubers in the altiplano in Peru [8]. The presence of strains belonging to the "P. peruviense" specie in two independent environmental samples in France indicates that the geographic distribution of this specie is likely to be larger than previously anticipated. Both French strains are able to rot potato tubers like the proposed type strain UG32. The two French isolates are more closely related to each other than they are with the type strain UGC32. Whether this reflects the geographic provenance (France vs Peru) or the niche provenance (water vs diseased plants) is unknown.

\section{Additional files}

Additional file 1: FigureS1. Symptoms observed on potato tubers. Overnight cultures of bacterial strains A97-S13-F16 and A350-S18-N16 were suspended in $50 \mathrm{mM}$ phosphate buffer $\mathrm{pH} 6.8$ and adjusted to 1.0 at $\mathrm{OD}_{580 \mathrm{~nm}}$. Tubers of $\mathrm{S}$. tuberosum var. charlotte were inoculated with $10 \mu \mathrm{l}$ of the cell suspension and placed at room temperature on wet paper towel in a plastic box. Six days post-infection, tubers were cut in half and representative symptoms are shown: A: A97-S13-F16, B: A350S18-N16, C: 50 mM phosphate buffer pH 6.8. (DOCX 9779 kb)
Additional file 2: Table S1. ANIb and dDDH pairwise values. $\mathrm{dDDH}$ and ANIb are respectively presented in the upper and lower part of the matrix triangle. Strains belonging to the same species are highlighted in red. Specific threshold value is $96 \%$ for ANIb and $70 \%$ for DDH. ANIb values were computed using the Blast algorithm of the Jspecies package [23]. dDDH were calculated according to [22]. (DOCX $79 \mathrm{~kb}$ )

\begin{abstract}
Abbreviations
ANI: Average Nucleotide Identity; COG: Clusters of Orthologous Groups; CRISPR: Clustered Regularly Interspaced Short Palindromic Repeats; dDDH: digital DNA-DNA hybridization; gapA: glyceraldehyde-3-phosphate dehydrogenase A; MLSA: Multi Locus Sequence Analysis; NTU: Normalized Turbidity Unit; sp.: specie; subsp.: subspecie
\end{abstract}

\section{Acknowledgements}

This work has benefited from the expertise of the High-Throughput Sequencing Platform of I2BC, Gif sur Yvette, France. We thank our British colleague Emma Rochelle Newall for english editing of the manuscript. We thank Odile Berge and Frédérique Van Gijsegem for their help during river samplings and Ariane Toussaint and Antoine Pourbaix for hosting us during the field samplings.

\section{Funding}

This work is supported by Agence Nationale de la Recherche (COMBICONTROL, grant ANR-15-CE21-0003) and CNRS program (EC2CO- Biohefect/Ecodyn//Dril/MicrobiEenCARTOBACTER).

\section{Availability of data and materials}

This Whole Genome Shotgun project has been deposited at DDBJ/ENA/ GenBank under the accessions PYUO00000000 and PYUP00000000. The versions described in this paper are versions PYU001000000 and PYUP01000000. The strains are available at the CIRM CFBP. 


\section{Authors' contributions}

BMA initiated the study and provided and background information. BMA and $C B$ isolated the strains. CB performed the gapA amplification and phylogenetic analysis, isolated the DNA for sequencing and performed the microscopy analysis. JP and FP assembled, analyzed the genomes and conducted the MLSA analysis. BMA and JP wrote the manuscript. All authors read and approved the final manuscript.

\section{Ethics approval and consent to participate}

not applicable.

\section{Consent for publication}

not applicable.

\section{Competing interests}

The authors declare that they have no competing interests.

\section{Publisher's Note}

Springer Nature remains neutral with regard to jurisdictional claims in published maps and institutional affiliations.

Received: 20 May 2018 Accepted: 28 September 2018

Published online: 12 October 2018

\section{References}

1. Skerman VB, McGowan V, Sneath PH. Approved lists of bacterial names. Int J Syst Bacteriol. 1980;30:225-420.

2. Ma B, Hibbing ME, Kim H-S, Reedy RM, Yedidia I, Breuer J, et al. Host range and molecular phylogenies of the soft rot Enterobacterial genera Pectobacterium and Dickeya. Phytopathology. 2007;97:1150-63.

3. Pérombelon M, Kelman A. Ecology of the soft rot Erwinias. Annu Rev Phytopathol. 1980;18:361-87.

4. Gardan L, Gouy C, Christen R, Samson R. Elevation of three subspecies of Pectobacterium carotovorum to species level: Pectobacterium atrosepticum sp. nov., Pectobacterium betavasculorum sp. nov. and Pectobacterium wasabiae sp. nov. Int J Syst Evol Microbiol. 2003;53:381-91.

5. Nabhan S, De Boer SH, Maiss E, Wydra K. Pectobacterium aroidearum sp. nov. , a soft rot pathogen with preference for monocotyledonous plants. Int J Syst Evol Microbiol. 2013;63:2520-5.

6. Dees MW, Lysøe E, Rossmann S, Perminow J, Brurberg MB. Pectobacterium polaris sp. nov., isolated from potato (Solanum tuberosum). Int J Syst Evol Microbiol. 2017;67:5222-9.

7. Khayi S, Cigna J, Chong T, Quêtu-Laurent A, Chan K, Helias V, et al. Transfer of the potato plant isolates of Pectobacterium wasabiae to Pectobacterium parmentieri sp. nov. Int J Syst Evol Microbiol. 2016;66:5379-83.

8. Waleron M, Misztak A, Waleron M, Franczuk M, Wielgomas B, Waleron K. Transfer of Pectobacterium carotovorum subsp. carotovorum strains isolated from potatoes grown at high altitudes to Pectobacterium peruviense sp. nov. Syst Appl Microbiol. 2018:41:85-93.

9. Hauben L, Moore ERB, Vauterin L, Steenackers M, Mergaert J, Verdonck L, et al. Phylogenetic position of Phytopathogens within the Enterobacteriaceae. Syst Appl Microbiol. 1998;21:384-97.

10. List Editor: Validation List no. 68. Validation of publication of new names and new combinations previously effectively published outside the IJSB. Int J Syst Bacteriol. 1999:49:1-3.

11. Koh Y, Kim G, Lee Y, Sohn S, Koh H, Kwon S, et al. Pectobacterium carotovorum subsp. actinidiae subsp. nov., a new bacterial pathogen causing canker-like symptoms in yellow kiwifruit, Actinidia chinensis. N Z J Crop Hortic Sci. 2012:40:269-79.

12. Nabhan S, De Boer SH, Maiss E, Wydra K. Taxonomic relatedness between Pectobacterium carotovorum subsp. carotovorum, Pectobacterium carotovorum subsp. odoriferum and Pectobacterium carotovorum subsp. brasiliense subsp. nov. J Appl Microbiol. 2012;113:904-13.

13. Panda P, Fiers MWEJ, Lu A, Armstrong KF, Pitman AR. Draft genome sequences of three Pectobacterium strains causing blackleg of potato: $P$. carotovorum subsp. brasiliensis ICMP 19477, P. atrosepticum ICMP 1526, and P. carotovorum subsp. carotovorum UGC32. Genome Announc. 2015;3: e00874-15.

14. Hélias V, Hamon P, Huchet E, Wolf JVD, Andrivon D. Two new effective semiselective crystal violet pectate media for isolation of Pectobacterium and Dickeya: isolating pectolytic bacteria on CVP. Plant Pathol. 2012;61:339-45.
15. Cigna J, Dewaegeneire P, Beury A, Gobert V, Faure D. A gapA PCRsequencing assay for identifying the Dickeya and Pectobacterium potato pathogens. Plant Dis. 2017;101:1278-82.

16. Aziz RK, Bartels D, Best AA, DeJongh M, Disz T, Edwards RA, et al. The RAST server: rapid annotations using subsystems technology. BMC Genomics. 2008:9:75.

17. Delcher AL, Harmon D, Kasif S, White O, Salzberg SL. Improved microbial gene identification with GLIMMER. Nucleic Acids Res. 1999;27:4636-41.

18. Marchler-Bauer A, Bryant SH. CD-search: protein domain annotations on the fly. Nucleic Acids Res. 2004;32:W327-31

19. Grissa I, Vergnaud G, Pourcel C. CRISPRFinder: a web tool to identify clustered regularly interspaced short palindromic repeats. Nucleic Acid Res. 35: W52-W57.

20. Petersen TN, Brunak S, von HG, Nielsen H. SignalP 4.0: discriminating signal peptides from transmembrane regions. Nat Methods. 2011:8:785-6.

21. Krogh A, Larsson B, von Heijne G, Sonnhammer EL. Predicting transmembrane protein topology with a hidden markov model: application to complete genomes11Edited by F. Cohen. J Mol Biol. 2001;305:567-80

22. Meier-Kolthoff JP, Auch AF, Klenk HP, Göker M. Genome sequence-based species delimitation with confidence intervals and improved distance functions. BMC Bioinformatics. 2013;14:60.

23. Richter M, Rosselló-Móra R, Oliver Glöckner F, Peplies J. JSpeciesWS: a web server for prokaryotic species circumscription based on pairwise genome comparison. Bioinforma Oxf Engl. 2016;32:929-31.

24. Edgar RC. MUSCLE: a multiple sequence alignment method with reduced time and space complexity. BMC Bioinformatics. 2004:5:113.

25. Castresana J. Selection of conserved blocks from multiple alignments for their use in phylogenetic analysis. Mol Biol Evol. 2000;17:540-52.

26. Guindon S, Gascuel O. A simple, fast, and accurate algorithm to estimate large phylogenies by maximum likelihood. Syst Biol. 2003;52:696-704.
Ready to submit your research? Choose BMC and benefit from:

- fast, convenient online submission

- thorough peer review by experienced researchers in your field

- rapid publication on acceptance

- support for research data, including large and complex data types

- gold Open Access which fosters wider collaboration and increased citations

- maximum visibility for your research: over $100 \mathrm{M}$ website views per year

At $\mathrm{BMC}$, research is always in progress.

Learn more biomedcentral.com/submissions 